\title{
DETERMINING THE INTERACTIONS OF BLACK PINE NET PRIMARY PRODUCTIVITY AND FOREST STAND PARAMETERS IN NORTHERN TURKEY
}

\author{
BULUT, S. $.^{*}-$ SATIR, O. ${ }^{2}-$ GÜNLÜ, A. ${ }^{1}$ \\ ${ }^{1}$ Faculty of Forestry, Çankırı Karatekin University, Çankırı, Turkey \\ ${ }^{2}$ Faculty of Architecture and Design, Department of Landscape Architecture, Yuzuncu Yil \\ University, Van, Turkey \\ *Corresponding author \\ e-mail: sbulut@karatekin.edu.tr; phone: +90-376-212-2757 \\ (Received 22 $2^{\text {nd }}$ Jan 2019; accepted $22^{\text {nd }} F e b 2019$ )
}

\begin{abstract}
Net primary productivity (NPP) is a vital dataset to assess carbon cycling, carbon budget and interpreting global warming. There are many approaches to calculate NPP, and Carnegie-Ames-Stanford approach (CASA) is one of the most popular approaches that was applied in this study. Black pine forest NPP was calculated with the CASA model in a transection zone between humid black sea and dry middle Anatolia region of Turkey for the year of 2016. Model parameters and homogeneity were tested with one-way ANOVA. Results was showed that annual NPP values were varied from 194 to $1213\left(\mathrm{~g} \mathrm{C} \mathrm{m}^{-2}\right.$ year $\left.{ }^{-1}\right)$ for pure black pine stands. Model validation was made with stand increment, growing stock, and stand carbon values. Correlation co-efficiencies were obtained to be 0.92 and 0.85 respectively. It was found that NPP was higher in young stands where the mass accumulation potential was higher than areas, where crown closure was between $11 \%$ and $70 \%$. According to this study, young stands should be established in the forests that were operated with the highest NPP objective. NPP models that can be used on a global scale is required intense data and time consuming. In addition, it has been determined that mechanical models which are allowed more practical calculation and can be used with the stand parameters easily.
\end{abstract}

Keywords: black pine ecosystem, CASA model, forest productivity, stand attributes, forest characterization

\section{Introduction}

Net primary productivity (NPP) is an important indicator on terrestrial carbon cycle from local to global scales. It is the net amount of carbon the plant cover receives after the photosynthetic activity. The sum of autotrophic respiration and NPP is gross primary productivity (GPP). GPP is a parameter that is not directly measured and also measurement of autotrophic respiration is laborious (Gower et al., 1999; Berberoğlu et al., 2007; Ardö, 2015; Chen et al., 2016; Wang et al., 2018).

NPP is an important key variable in terms of carbon trading, which was established by 180 countries in 1997 Kyoto Protocol to reduce carbon emissions and global warming. Countries that has high carbon emissions, have been allowed to purchase more carbon dioxide emissions to the atmosphere from the countries with lower carbon emissions thanks to this agreement (Dong and Whalley, 2010; Klein et al., 2016). Forests are our one of the most efficient weapon in the battle with global warming and climate change. NPP can be used as indicator and control variable on this issue. It will be right strategy to cultivating forests with maximum NPP in this struggle in appropriate regions according to the ecological requirements.

There are many models that can be used to calculate NPP. These models are divided into three categories (Cramer et al., 1999; Schloss et al., 1999; Ruimy et al., 1999). First group is based on satellite data such as CASA (Potter et al., 1993), GLO-PEM (Prince, 1991), 
SDBM (Knorr and Heimann, 1995), TURC (Ruimy et al., 1996) and SIB2 (Sellers et al., 1996). Second group is based on seasonal biogeochemical fluxes such as HRBM3.0 (Esser et al., 1994), CENTURY4.0 (Parton et al., 1993), TEM4.0 (McGuire et al., 1995) and SILVAN2.2 (Kaduk and Heimann, 1996). Third group is based on seasonal biogeochemical fluxes and vegetation structure such as BIOME3 (Haxeltine and Prentice, 1996), DOLY (Woodward et al., 1995) and HYBRID3.0 (Friend, 1995).

Spatial NPP models particularly CASA model are widely applied from regional to global scale accurately using remotely sensed datasets (Turner et al., 2006; Wang et al., 2013). Liang et al. (2015) and Chen et al. (2016) used the CASA model to research the temporal and spatial changes in NPP of different vegetation types, from 1982 and 2010-from 1984 to 2014, respectively. Liu et al. (2018) estimated aboveground NPP using CASA model for forest ecosystems. Tripathi et al. (2018) selected CASA model to explore the spatiotemporal patterns of NPP for 2009 and 2010 years in forest plantations. Li and Zhou (2015) predicted NPP using CASA model for forest types and reported that how NPP changed by forest stand age.

In our study, we focused on areas where covered by black pine. Black pine trees have been started to use main afforestation tree against soil erosion and to mitigate the some land degradation effects in Turkey during the more than ten years. So this study also important to understand the black pine tree contribution to carbon budget of the country. The objectives of this study were; (i) to calculate the NPP with CASA model, (ii) to validate the CASA model system for pure black pine stands under continental climate conditions, (iii) to research model possibilities of NPP with stand parameters and (iv) to determine the optimal stand criteria for maximum NPP in pure black pine areas.

\section{Materials and methods}

\section{Study area}

The study area is located on the Black Sea backward region of Turkey (Fig. 1). The coordinates of the study area are between $33^{\circ} 21^{\prime} 56^{\prime \prime}$ - 33 $25^{\circ} 27^{\prime \prime}$ north latitude and $33^{\circ} 34^{\prime} 22^{\prime \prime}-33^{\circ} 20^{\prime} 01^{\prime \prime}$ east longitude. The study area is about 18488.30 ha and pure Anatolian black pine (Pinus nigra subsp. Pallasiana var. Pallasiana (Arnold)) stands are covered totally 5517.44 ha areas. There are also Scots pine (Pinus sylvestris), Poplar (Populus sp.) and Oak (Quercus sp.) in the region. The elevation has been varied between 1000 and $1600 \mathrm{~m}$.

Climate type of the study area is defined as semi-arid, mesothermal with excessive wetness during winters. Mean, maximum and minimum annual temperature are 11, 18 and $5{ }^{\circ} \mathrm{C}$, respectively. This area is one of the transection zones between Euro-Siberien and Irano-Turanian phytogeographical regions. Mean annual precipitation is $412 \mathrm{~mm}$. Daily total highest precipitation in the region is $74 \mathrm{~mm}$.

\section{Materials}

Three main materials were used in the study to be forest inventory, satellite dataset and climate dataset (Table 1).

\section{Forest inventory}

Data from national forest management inventories were used. Sample plots were taken systematically at intervals of $300 \times 300 \mathrm{~m}$. According to the crown closure of the sample 
plots, sample point size was chosen from low $\left(11-40 \%=800 \mathrm{~m}^{2}\right)$, medium $(41-70 \%=600$ $\left.\mathrm{m}^{2}\right)$ and full crown closure $\left(71-100 \%=400 \mathrm{~m}^{2}\right)$. Then, diameter at breast height (DBH, $1.30 \mathrm{~m}$ ), age and height were measured in all trees with a diameter greater than $7.9 \mathrm{~cm}$ in each sample plot (Anonymous, 2008). Stand map was prepared using combine inventory method through satellite image or aerial photograph and field measurements and 2015-2016 plot measurements were used in this study. Detailed stand area, stand increment and growing stock tables were added to forest management plan.

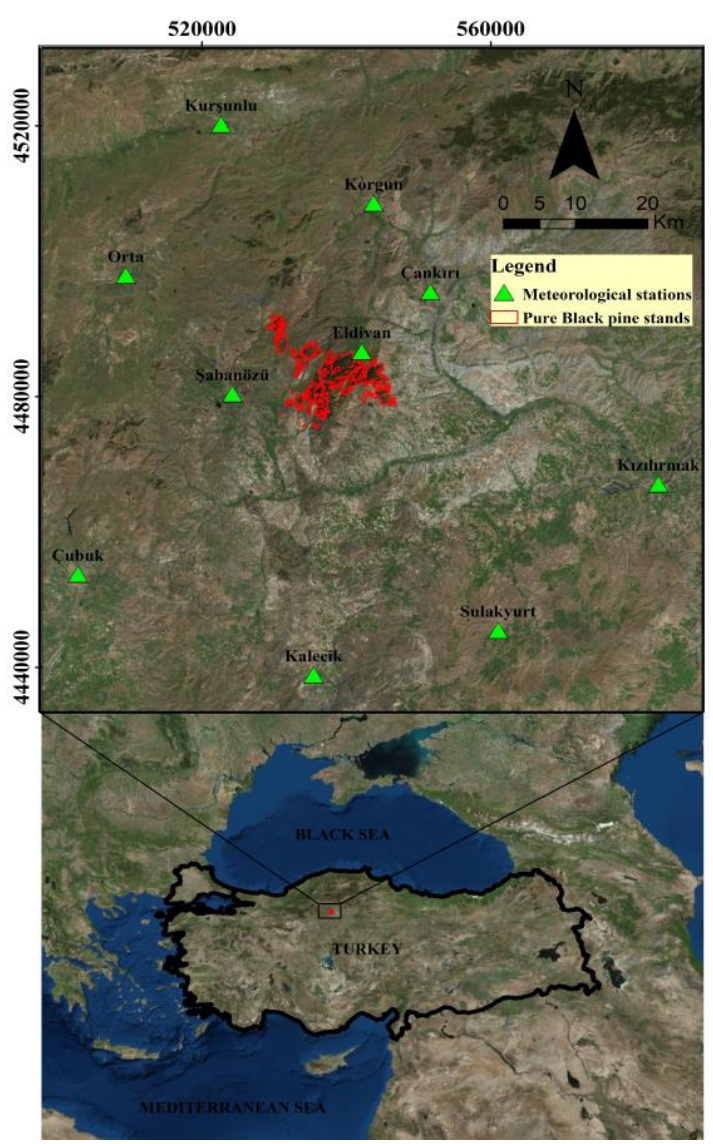

Figure 1. Study area

Table 1. Characterizations of the study materials

\begin{tabular}{c|c|c}
\hline Dataset & Usage purpose & Source \\
\hline Forest inventory & Ground truth of NPP, comparison & Republic of Turkey, General \\
& analyses & Directorate of Forestry \\
Satellite dataset & NPP calculations & USGS Landsat database \\
Climate dataset & NPP calculations & State meteorological works of Turkey \\
\hline
\end{tabular}

\section{Satellite data}

Landsat 8 satellite images were acquired for each month of 2016 from the United States Geological Survey Earth Explorer data portal (USGS, 2000). Band 4 (Red), Band 5 (Near Infrared) and Band 7 (Short-wave Infrared) were used to run the CASA model for twelve months of a year. 


\section{Meteorological data}

Climate data were included daily mean, maximum, minimum temperature, precipitation and solar radiation with the same periods of Landsat image's records (2015-2016) and obtained from 10 Turkish State Meteorological Service climate stations. Monthly mean, maximum, minimum temperature and solar radiation were interpolated with appropriate interpolation techniques such as ordinary kriging and radial basis function. Climate data maps prepared for the study area were produced with $30 \mathrm{~m}$ spatial resolutions. Data interpolation and analysis were performed using.

\section{Methodology}

\section{The CASA model}

Carnegie, Ames, Stanford Approach (CASA) model was used to predict Black pine NPP in local scale (Potter et al., 2003, 2004). This model is run based on photosynthesis progress of a plant. It was designed for global studies, however; it is contained plant specific variables and it may be used for the local studies for modifying the variables such as maximum light use efficiency and photosynthesis temperature range.

The CASA model was used for predicting NPP in the study area. It is defined as follows $(E q .1)$ :

$$
N P P=\varepsilon_{n} x A P A R
$$

where APAR is absorbed photosynthetically active radiation $\left(\mathrm{MJ} / \mathrm{m}^{2}\right.$ month) and $\varepsilon_{\mathrm{n}}$ is light use efficiency ( $\mathrm{g} \mathrm{C} / \mathrm{MJ})$.

$$
\varepsilon_{n}=\varepsilon_{\max } x f(T) x f(W)
$$

Maximum light use efficiency $\left(\varepsilon_{\max }\right)$ for evergreen needleleaf stands was separated into three age classes. Mean $\varepsilon_{\max }$ of young, middle age and mature stands are 0.72, 0.57 and 0.52 (g C/MJ), respectively ( $\mathrm{Li}$ and Zhou, 2015).

Temperature on the maximum light use efficiency of vegetation $(\mathrm{T})$ is defined as follows (Eq. 3):

$$
f(T)=\left(T-T_{\min }\right) x\left(T-T_{\max }\right) /\left(\left(T-T_{\min }\right) x\left(T-T_{\max }\right)\right)-\left(T-T_{\text {opt }}\right)^{2}
$$

where $\mathrm{T}$ is the atmospheric temperature $\left({ }^{\circ} \mathrm{C}\right)$; and $\mathrm{T}_{\min }, \mathrm{T}_{\mathrm{opt}}$, and $\mathrm{T}_{\max }$ are the minimum, optimal, and maximum temperatures $\left({ }^{\circ} \mathrm{C}\right)$ for photosynthetic activities, respectively (Huang et al., 2010).

Water on the maximum light use efficiency of vegetation (W) is defined as follows (Eqs. 4 and 5):

$$
\begin{gathered}
W=(1+L S W I) /\left(1+L S W I_{\text {max }}\right) \\
L S W I=\left(p_{\text {nir }}-p_{\text {swir }}\right) /\left(p_{\text {nir }}+p_{\text {swir }}\right)
\end{gathered}
$$


where LSWI is the land surface water index and LSWI $I_{\max }$ is the maximum LSWI. The variables $p_{\text {nir }}$ and $p_{\text {swir }}$ represent the surface reflectance of the NIR and MIR bands in Landsat 8 images, respectively (Huang et al., 2010).

$$
A P A R=F P A R \times P A R
$$

Fraction of photosynthetically active radiation (FPAR) is defined as follows (Eq. 7):

$$
F P A R=\frac{\left(N D V I-N D V I_{\min }\right) X 0.95}{\left(N D V I_{\max }-N D V I_{\min }\right)}+0.05
$$

where NDVI is Normalized Difference Vegetation Index, $\mathrm{NDVI}_{\max }$ and $\mathrm{NDVI}_{\min }$ are the maximum and minimum Normalized Difference Vegetation Index, respectively (Los et al., 2000; Zhu et al., 2006; Huang et al., 2010; Chen et al., 2016).

Photosynthetically active radiation (PAR) is defined as follows (Eq. 8):

$$
P A R=\operatorname{Sr} x 0.50
$$

where $\mathrm{Sr}$ is solar radiation $\left(\mathrm{MJ} / \mathrm{m}^{-2} \mathrm{day}^{-1}\right)$ (Potter, 1993, 1998; Huang et al., 2010).

\section{Tree cover classification}

Stand map was acquired from Turkey General Directorate of Forestry to determine the pure black pine cover. The stand map is contained the classification of the area according to the tree type, development age and crown closure. Within these areas, there may be areas that are not covered by trees because it was obtained as polygons and caver degree is variable inside the polygons. Therefore, only forest covered areas were extracted from the polygons applying a supervised classification approach. NPP will be calculated for pure black pine areas, so the opening areas had to be removed. We used maximum likelihood classification method (MLC) that is one of the most effective parametric classifier when there are enough training points for forest cover classification (Şatır and Berberoğlu, 2012). Almost 270 training points were used to be forest and non-forest areas, and 100 points were used for accuracy assessment. This area is not too complex, also it is included only black pine forest formation so point samples were enough for the classification.

\section{Calculating carbon stock}

Initial parameter in calculating the carbon stock was total stand growing stock volume (V), and it was obtained from stand map and forest management plan. Other parameters were above-ground biomass (AGB), below-ground biomass (BGB), aboveground carbon (AGC), below-ground carbon (BGC), dead wood biomass (DWB), dead wood carbon (DWC), litter carbon (LC) and forest soil carbon (FSC). The carbon stocks in the biomass were calculated using AGC, BGC, DWC, LC and FSC (Eq. 9; Tolunay, 2011; Değirmenci and Zengin, 2016). The equations of these parameters were presented in Table 2.

$$
\text { Carbon stock }=A G C+B G C+D W C+L C+F S C
$$


Table 2. Carbon stock coefficients

\begin{tabular}{c|c|c}
\hline Cover type & Parameter & Equation \\
\hline \multirow{5}{*}{ Coniferous } & AGB & V x 0.446 $\times 1.212$ \\
& BGB & AGB $\times 0.29$ \\
& AGC & AGB $\times 0.51$ \\
& BGC & BGB $\times 0.51$ \\
& DWB & AGB $\times 0.01$ \\
& DWC & DWB 0.47 \\
& LC & Area (ha) $\times 7.46$ \\
& FSC & Area (ha) $\times 76.56$ \\
\hline
\end{tabular}

\section{Variance analysis}

Digital Elevation Model (DEM), forest management plan and stand map were used for calculating testing parameters to be age, site index, crown closure and elevation. Homogeneity between NPP and these parameters was tested using one-way ANOVA by followed Duncan procedure. Classes were created for elevation, age, crown closure and site index (Table 3). Elevation was between 1000 and $1600 \mathrm{~m}$ in the study area. It was separated into six classes. Age was created as a seven classes with a period of 20 years. There are no stands of the sixth age class in the study area. Crown closure was divided into three classes by coverage of ground cover. Site index was determine according to dominant height at standard age (100) and separated into three classes.

Table 3. Classes for variance analysis

\begin{tabular}{c|c|c|c|c|c}
\hline Criteria & Value & Class & Criteria & Value & Class \\
\hline \multirow{5}{*}{ Age (year) } & $0-20$ & 1 & & $1000-1100$ & 1 \\
& $21-40$ & 2 & & $1101-1200$ & 2 \\
& $41-60$ & 3 & & $1201-1300$ & 3 \\
& $61-80$ & 4 & Elevation (m) & $1301-1400$ & 4 \\
& $81-100$ & 5 & & $1401-1500$ & 5 \\
& $121-140$ & 6 & & $1501-1600$ & 6 \\
\hline \multirow{3}{*}{ Site index (m) } & $20-24$ & 1 & & $11-40$ & 1 \\
& $15-19$ & 2 & Crown closure (\%) & $41-70$ & 2 \\
& $10-14$ & 3 & & $71-100$ & 3 \\
\hline
\end{tabular}

\section{The validation of CASA model}

NPP was predicted using the CASA model and we did not have actual values to validation of the model. So, stand increment, growing stock and stand carbon were used for the CASA model validation. The relationships between these parameters and NPP were compared. Relationship levels were determined by calculating correlation ( $\mathrm{r}$ ) and coefficient of determination $\left(\mathrm{R}^{2}\right)$. In addition, CASA model was compared and validated in many studies (Cramer et al., 1999; Potter et al., 2012), and these were showed that this model was provided significant results when it was applied correctly. 


\section{Results}

Study results were presented in three stages to be; mapping the tree cover, mapping of the NPP, and defining the relationship between NPP and some forest stand variables.

\section{Mapping the tree cover in black pine stands}

The CASA model used for NPP computation was created for tree covered fields. It was necessary to remove the opening areas. So the NPP was more consistently calculated in terms of spatial position. For the operation of this process, Landsat 8 satellite image was used for supervised classification (kappa $=0.92$, overall accuracy $=96.4 \%)$. The opening and tree cover areas were determined and NPP was calculated to tree cover areas (Fig. 2).

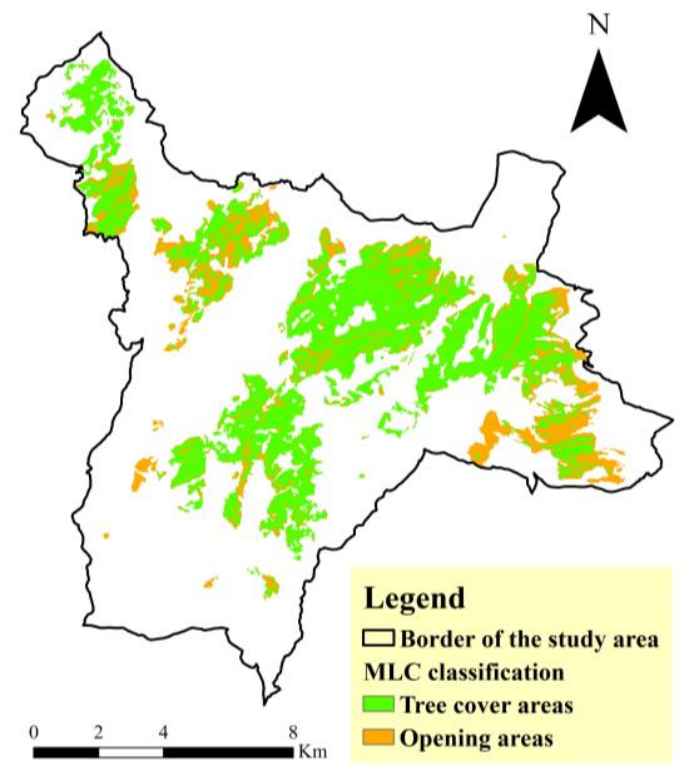

Figure 2. Tree cover map of the black pine stands

\section{Mapping the NPP using CASA model}

The CASA model was used to predict NPP values of the pure black pine forests in 2016. NPP values were integrated with forest stand map and calculated variables such as stand increment, growing stock and stand carbon in 676 plots. Descriptive statistics for NPP, stand increment, growing stock and stand carbon were presented in Table 4. The NPP values ranged between 15.16 and 1893.93 (ton $C$ year ${ }^{-1}$ ) with a mean value of 382.82 (ton $\mathrm{C}$ year ${ }^{-1}$ ). Mean values of stand increment, growing stock and stand carbon were defined to be $20.90,548.79$ and 677.57 , respectively.

Table 4. Descriptive statistics of the NPP and forest attributes

\begin{tabular}{c|c|c|c|c|c|c|c}
\hline Variable & N & Min & Max & Mean & SD & Skew & Kurt \\
\hline NPP (ton C year-1) & 676 & 15.16 & 1893.93 & 382.82 & 385.26 & 1.651 & 2.306 \\
Stand increment $\left(\mathrm{m}^{3}\right)$ & 676 & 0.60 & 175.39 & 20.90 & 27.07 & 2.468 & 6.756 \\
Growing stock $\left(\mathrm{m}^{3}\right)$ & 676 & 7.32 & 4010.47 & 548.79 & 746.09 & 2.024 & 3.813 \\
Stand carbon (ton C year-1) & 676 & 45.30 & 4221.33 & 677.57 & 716.82 & 1.831 & 3.193 \\
\hline
\end{tabular}


Monthly mean NPP values were calculated for all months of 2016 (Fig. 3). The highest mean NPP was calculated in May to be $120.83\left(\mathrm{~g} \mathrm{C} \mathrm{m}^{-2} \mathrm{month}^{-1}\right)$ and the lowest mean NPP was calculated in February as $5.89\left(\mathrm{~g} \mathrm{C} \mathrm{m}^{-2}\right.$ month $\left.^{-1}\right)$. According to the monthly analyses, there was a significant improvement on NPP in March, April and May. However, NPP was decreased fast after the September. The highest NPP value was predicted to be $1213.40\left(\mathrm{~g} \mathrm{C} \mathrm{m}^{-2}\right.$ year $\left.^{-1}\right)$ and the lowest NPP value was 193.70 (g C $\mathrm{m}^{-2}$ year $^{-1}$ ) per unit area over the year (Fig. 4).

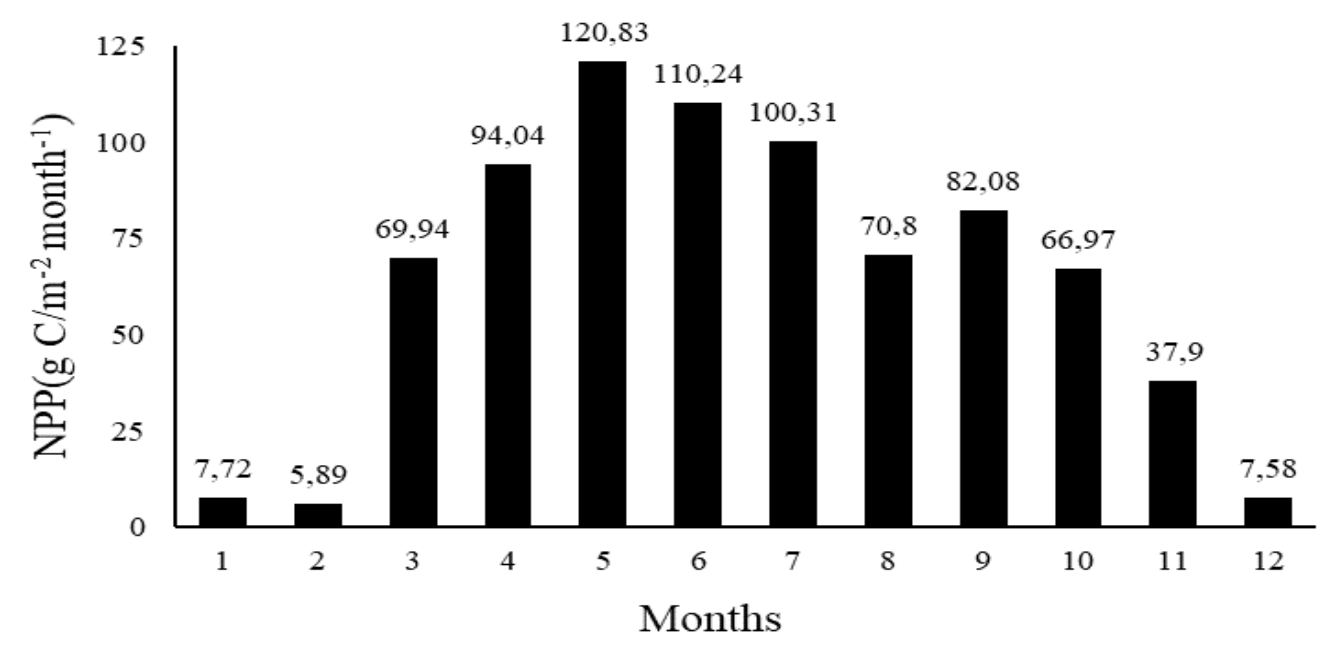

Figure 3. NPP distribution in the pure black pine stands for months of 2016

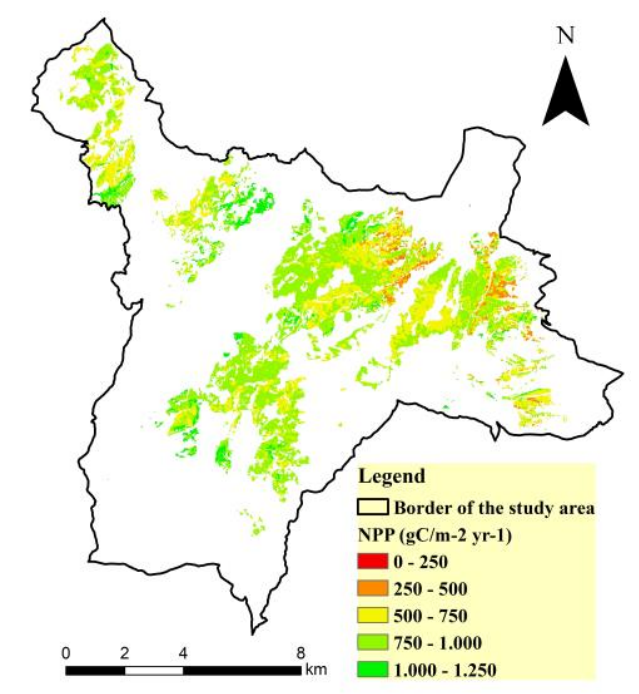

Figure 4. Spatial distribution of NPP derived from the CASA model in the black pine stands for the year 2016

\section{Defining the relationship between NPP and some forest attributes}

Relationship levels between the calculated NPP data and stand increment, growing stock and stand carbon were showed in Table 5 and Figure 5. The highest correlation was obtained with stand carbon $(\mathrm{r}=0.92)$, and the lowest correlation was defined with stand increment $(r=0.87)$. Linear models and relationships were created between NPP 
and these variables. Linear model results were showed that predicted NPP and calculated stand variables related with NPP were matched, and NPP prediction was significant for this area.

Table 5. NPP models and performance criteria

\begin{tabular}{c|c|c|c|c|c}
\hline Variable & $\mathbf{N}$ & Model & $\mathbf{r}$ & $\mathbf{R}^{\mathbf{2}}$ & $\mathbf{p}$ \\
\hline Stand increment $\left(\mathrm{m}^{3}\right)$ & 676 & $\mathrm{NPP}=(12.351 \times$ Stand increment $)+124.69$ & 0.87 & 0.75 & 0.000 \\
Growing stock $\left(\mathrm{m}^{3}\right)$ & 676 & $\mathrm{NPP}=(0.4552 \times$ Growing stock $)+133.04$ & 0.88 & 0.78 & 0.000 \\
Stand carbon (ton $\mathrm{C}$ year-1) & 676 & $\mathrm{NPP}=(0.4954 \times$ Stand carbon $)+47.155$ & 0.92 & 0.85 & 0.000 \\
\hline
\end{tabular}
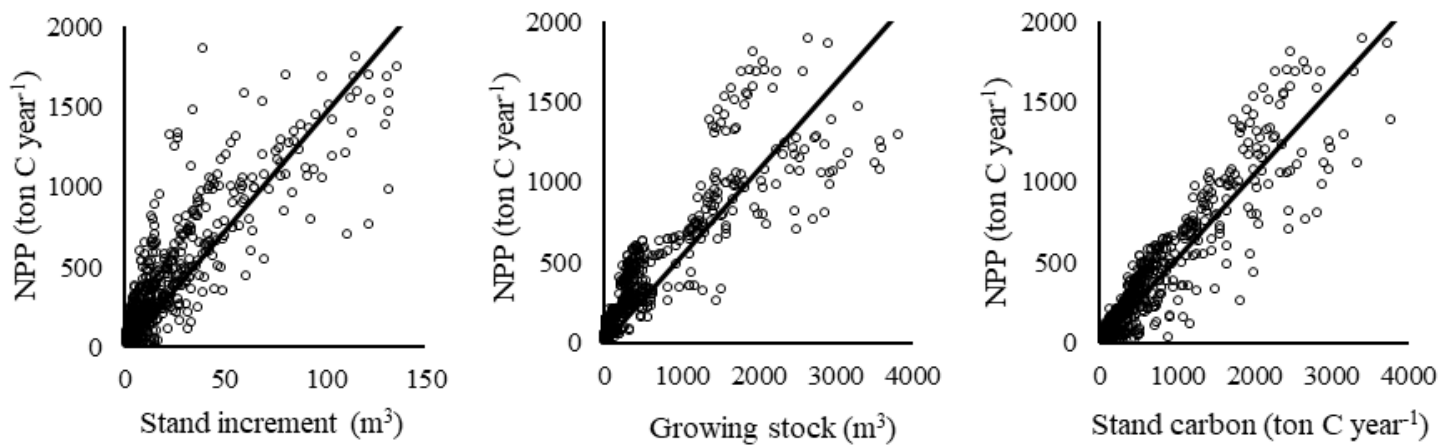

Figure 5. Comparison between NPP and validation parameters

Results of the one - way ANOVA test were summarized in Table 6. Duncan test showed that NPP values were statistically different by age $(\mathrm{F}=88.465, \mathrm{p}<0.05)$, elevation $(\mathrm{F}=39.354, \mathrm{p}<0.05)$, site index $(\mathrm{F}=63.118, \mathrm{p}<0.05)$ and crown closure $(\mathrm{F}=23.114, \mathrm{p}<0.05)$. According to the results, age classes were divided into 5 groups $(\mathrm{a}<\mathrm{b}<\mathrm{c}<\mathrm{d}<\mathrm{e})$, elevation classes were divided into 3 groups $(\mathrm{a}<\mathrm{b}<\mathrm{c})$, site index and crown closure classes were divided into 2 groups $(\mathrm{a}<\mathrm{b})$. Results showed that NPP was higher in young and low-medium closed stands than old stands in an altitude of 1300-1600 $\mathrm{m}$ with an average dominant height of 12-17 $\mathrm{m}$.

Table 6. Comparison of stand parameters in terms of NPP according to one-way ANOVA by followed Duncan

\begin{tabular}{|c|c|c|c|c|c|c|c|}
\hline Criteria & Class & $\mathbf{N}$ & Mean & Criteria & Class & $\mathbf{N}$ & Mean \\
\hline \multirow{6}{*}{ Age (year) } & 1 & 87 & $946.30^{\mathrm{e}}$ & \multirow{6}{*}{ Elevation (m) } & 1 & 53 & $670.13^{\mathrm{a}}$ \\
\hline & 2 & 510 & $849.91^{\mathrm{d}}$ & & 2 & 278 & $686.12^{\mathrm{a}}$ \\
\hline & 3 & 935 & $743.97^{\mathrm{b}}$ & & 3 & 470 & $766.84^{\mathrm{b}}$ \\
\hline & 4 & 245 & $778.67^{\mathrm{c}}$ & & 4 & 714 & $799.54^{\mathrm{c}}$ \\
\hline & 5 & 827 & $750.33^{b}$ & & 5 & 723 & $793.62^{\mathrm{bc}}$ \\
\hline & 6 & 100 & $710.30^{\mathrm{a}}$ & & 6 & 466 & $777.65^{\mathrm{bc}}$ \\
\hline \multirow{3}{*}{ Site index (m) } & 1 & 828 & $730.81^{\mathrm{a}}$ & \multirow{3}{*}{ Crown closure $(\%)$} & 1 & 469 & $782.86^{\mathrm{b}}$ \\
\hline & 2 & 1727 & $792.21^{\mathrm{b}}$ & & 2 & 905 & $795.78^{\mathrm{b}}$ \\
\hline & 3 & 149 & $808.51^{\mathrm{b}}$ & & 3 & 1330 & $756.68^{\mathrm{a}}$ \\
\hline
\end{tabular}

$\mathrm{a}, \mathrm{b}, \mathrm{c}, \mathrm{d}$ and e letters show groups that are statistically different each other at $95 \%$ significance level $(\mathrm{a}<\mathrm{b}<\mathrm{c}<\mathrm{d}<\mathrm{e})$ 


\section{Discussion}

NPP was quite low in the first two months of the year. This situation was caused by the seasonal low temperature, solar radiation and leave chlorophyll activities (NDVI). NPP was increased rapidly in March and reached the highest value in May because of ideal weather conditions (precipitation, temperature and solar radiation) for black pine photosynthesis process. Summer temperatures were between $19-22{ }^{\circ} \mathrm{C}$, and the highest temperature were recorded in August based on the nearest climate station. Therefore there was a little increase in September due to lower temperature than August. According to the NPP and temperature relationships, the ideal temperature for the black pine vegetation was defined to be $14.5-15^{\circ} \mathrm{C}$. NPP of the black pine vegetation was impacted from the temperature rise in June, July and August, negatively. NDVI in the last three months of the year was decreased regularly based on the weather conditions in these months. Particularly, temperature, precipitation and solar radiation were indicative on anomalies in seasonal transition (Fig. 3; Table 7).

Table 7. The monthly mean parameter values used in the CASA model

\begin{tabular}{c|c|c|c|c|c}
\hline Month & $\begin{array}{c}\text { Mean temperature } \\
\left({ }^{\circ} \mathbf{C}\right)\end{array}$ & $\begin{array}{c}\text { Mean precipitation } \\
(\mathbf{m m})\end{array}$ & $\begin{array}{c}\text { Mean solar radiation } \\
\left(\mathbf{M J} / \mathbf{m}^{-2}\right)\end{array}$ & $\mathbf{N D V I}$ & $\begin{array}{c}\mathbf{~ N P P} \\
\left(\mathbf{g ~ C ~} \mathbf{~ m}^{-2}\right)\end{array}$ \\
\hline January & -1.30 & 57.66 & 5.542 & 0.255 & 7.72 \\
February & 0.27 & 39.15 & 8.809 & 0.186 & 5.89 \\
March & 5.04 & 49.29 & 13.677 & 0.343 & 69.94 \\
April & 9.96 & 41.10 & 16.776 & 0.367 & 94.04 \\
May & 14.69 & 73.47 & 20.521 & 0.455 & 120.83 \\
June & 19.31 & 54.60 & 22.474 & 0.442 & 110.24 \\
July & 22.79 & 20.77 & 23.479 & 0.429 & 100.31 \\
August & 22.89 & 29.76 & 20.964 & 0.401 & 70.80 \\
September & 17.83 & 17.40 & 16.739 & 0.376 & 82.08 \\
October & 12.18 & 42.47 & 11.364 & 0.356 & 66.97 \\
November & 5.38 & 24.00 & 7.934 & 0.305 & 37.90 \\
December & 1.46 & 48.36 & 5.972 & 0.229 & 7.58 \\
\hline
\end{tabular}

There are many different models that can be used to calculate NPP. Schloss et al. (1999), Cramer et al. (1999) and Ruimy et al. (1999) compared the different global NPP models. Ruimy et al. (1999) evaluated twelve global NPP models and assessed the performance of the models. LUE was derived from models and obtained the linear correlation coefficients with NPP. The highest correlation between NPP and LUE was obtained with SIB model $(\mathrm{r}=0.71)$. APAR was also used in evaluation of the models. The highest accuracy was obtained by CASA model based on APAR $(r=0.98)$.

The CASA model is widely used in both locally and globally scales for NPP calculation. Taskınsu Meydan and Berberoglu (2008) performed NPP calculations for black pine stands in Mediterranean part of Turkey. Productivity evaluation can be made for northern and southern regions between continental and sub-Mediterranean climate zones. In this study, the lowest NPP value of the year was obtained in February (5.89 $\mathrm{g}$ $\mathrm{C} \mathrm{m}^{-2}$ month $\left.^{-1}\right)$, and the highest NPP value was obtained in May $\left(120.83 \mathrm{~g} \mathrm{C} \mathrm{m}^{-2} \mathrm{month}^{-1}\right)$. In the study conducted at the Mediterranean region, the lowest and highest values were detected in March and June (0.28-52.25 $\mathrm{g} \mathrm{C} \mathrm{m}^{-2}$ month $^{-1}$ ), respectively (Fig. 6). NPP 
obtained for the northern region was obviously higher than southern region of Turkey. The average for all months was $64.53 \mathrm{~g} \mathrm{C} \mathrm{m}^{-2}$ year $^{-1}$ for the northern region and $19.79 \mathrm{~g}$ $\mathrm{C} \mathrm{m}^{-2}$ year ${ }^{-1}$ for the southern region. Evrendilek et al. (2006) was estimated the NPP of conifer forests in the eastern Mediterranean region of Turkey. They presented that the annual total NPP of black pine forests was $1302.00 \mathrm{~g} \mathrm{C} \mathrm{m}^{-2}$ year-1. It was $774.30 \mathrm{~g} \mathrm{C} \mathrm{m}^{-2}$ year $^{-1}$ in our study. Because, studies were applied in different regions that has been various climatic conditions, and difference of the NPP values were significant even if they have similar land cover.

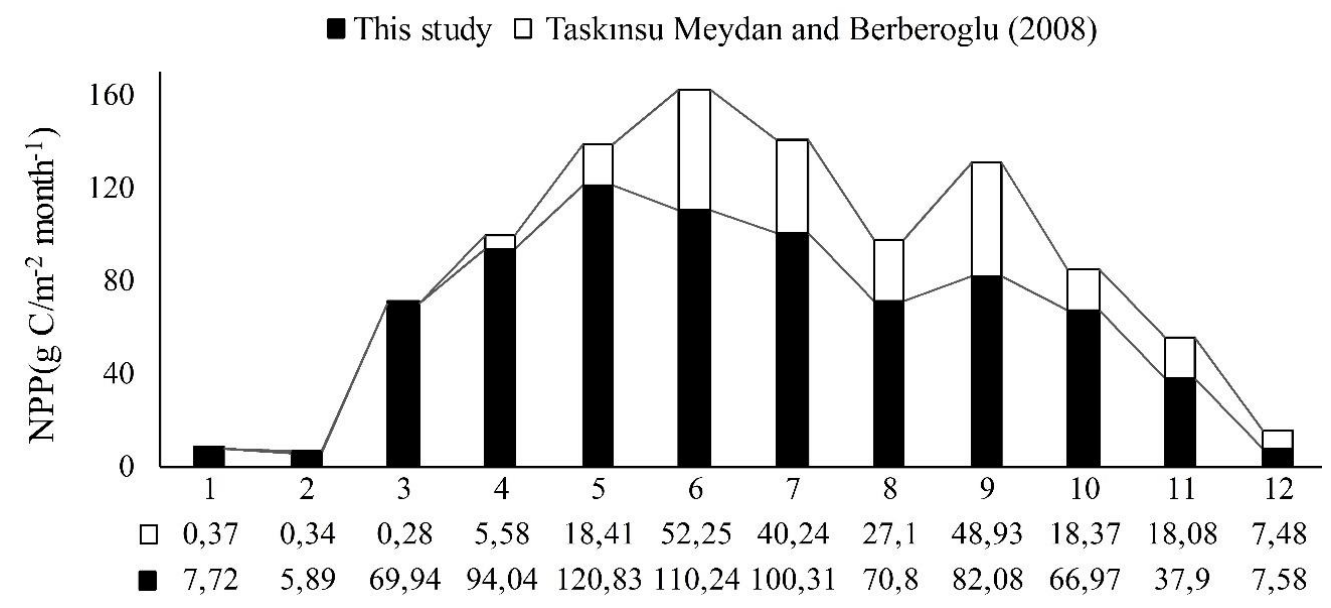

Figure 6. Comparison of monthly NPP values for pure black pine stands between southern and northern Turkey

Besides the climatic features, forest forms and land cover types were also affected to the NPP. Ma et al. (2008) were estimated the annual average NPP for Pinus elliottii plantation. They focused 20 years period from 1885 to 2005 . The average yearly GPP was predicted $630.88 \mathrm{~g} \mathrm{C} \mathrm{m}^{-2}$ year ${ }^{-1}$ by their study. In our study, the yearly NPP value was around $775 \mathrm{~g} \mathrm{C} \mathrm{m}^{-2}$ year $^{-1}$. In our work was done in natural pine forest, and their work was conducted in pine plantation areas that was included different pine species from our study. However, it can be seen clearly in Ma et al. (2008) that NPP values have been variable based on climatic effects.

Pei et al. (2018), Zhang and Zhang (2017) and Chen et al. (2016) were calculated the annual mean NPP using CASA model for different land cover types in China. Pei et al. (2018) obtained the NPP for evergreen broadleaf forest (EBF, $774 \mathrm{~g} \mathrm{C} \mathrm{m}^{-2}$ year $^{-1}$ ), deciduous broadleaf forest (DBF, $471 \mathrm{~g} \mathrm{C} \mathrm{m}^{-2}$ year $^{-1}$ ), evergreen needleleaf forest (ENF, $308 \mathrm{~g} \mathrm{C} \mathrm{m}^{-2}$ year-1), deciduous needleleaf forest (DNF, $444 \mathrm{~g} \mathrm{C} \mathrm{m}^{-2}$ year-1 $^{-1}$ ) and mixed forest (MIF, $460 \mathrm{~g} \mathrm{C} \mathrm{m}^{-2}$ year $^{-1}$ ). Zhang and Zhang (2017) reported that the NPP in ENF, DNF, DBF and MIF were 489.73, 415.71, 954.19 and $650.94 \mathrm{~g} \mathrm{C} \mathrm{m}^{-2}$ year ${ }^{-1}$. Chen et al. (2016) calculated the NPP for EBF $\left(771 \mathrm{~g} \mathrm{C} \mathrm{m}^{-2}\right.$ year $\left.{ }^{-1}\right)$ and DBF $\left(734 \mathrm{~g} \mathrm{C} \mathrm{m}^{-2}\right.$ year $\left.^{-1}\right)$. These differences in the NPP of land cover types were particularly affected by climate and topographic factors (Zhang and Zhang, 2017). Donmez et al. (2016) calculated the NPP using CASA model for 2000-2010 and estimated for 2070-2100 period using RCP climate scenarios in the eastern Mediterranean region of Turkey. The annual mean NPP was calculated $1042 \mathrm{~g} \mathrm{C} \mathrm{m-2} \mathrm{year-1} \mathrm{for} \mathrm{ENF} \mathrm{between} 2000$ and 2010. The highest and lowest NPP values were obtained for DBF (1529 $\mathrm{g} \mathrm{C} \mathrm{m}^{-2}$ year $\left.^{-1}\right)$ 
and shrubland (452 $\mathrm{g} \mathrm{C} \mathrm{m}^{-2}$ year $^{-1}$ ) cover types, respectively. The highest and lowest grand mean change according to RCP climate scenarios was obtained for the DBF ($3.2 \%$ ) and shrubland $(0.7 \%)$ cover type between $1476-1483 \mathrm{~g} \mathrm{C} \mathrm{m}^{-2}$ year $^{-1}$ and $454-$ $457 \mathrm{~g} \mathrm{C} \mathrm{m}^{-2}$ year $^{-1}$, respectively.

NPP is generally higher at young stands that are accumulating biomass in forest ecosystems (Field et al., 1995; Li and Zhou, 2015; Wang et al., 2018). As a result of the one-way ANOVA test applied to age classes $(6<3=5<4<2<1)$, NPP was higher in young stands that were $1^{\text {st }}$ and $2^{\text {nd }}$ age classes. The areas with an average dominant height of 12-17 m were more favorable than other areas for NPP $(1<2=3)$. Black pine covered areas in the study area were 5517 ha. Nearly half of the black pine areas (2303.19 ha) was located to $2^{\text {nd }}-3^{\text {rd }}$ site index and $1^{\text {st }}-2^{\text {nd }}-3^{\text {rd }}$ age classes. Thus, the NPP in areas with lower dominant height was found to be higher than other places because, these areas were covered by young stands with a high NPP. Wang et al. (2018) researched the relationship between age and NPP for broadleaved and conifer forests under the various site conditions. They reported that NPP of young forests increases rapidly, reaches the highest value in mature forests and decreases in old forests. In addition to the forest age, site conditions also affect the NPP. Chen et al. (2002) indicated that NPP was increasing faster in area of the high site index. That is, site index is critical in identifying the relationship between NPP and age.

When the results were examined in terms of the elevation that a linear relationship was appeared between NPP and elevation in negative way. Donmez et al. (2015) reported that there were an inverse relationship between NPP and elevation $\left(R^{2}=0.8129\right)$. Both studies were similar results in same points of view. This study was carried out for an area of 1000000 ha and an elevation range of $0-2300 \mathrm{~m}$. These results for site index and elevation have been influenced by the local and managed forest area.

NPP was higher in stands with low-medium crown closure (11-70\%) than high crown closure areas because of the efficient sun light availability. NPP may be high because the rate of fall to the surface of rain and the rate of water utilization of plants are high (especially in arid or semi-arid climates). These effects may have an enhancing effect on photosynthesis. So it may be caused NPP to increase.

\section{Conclusions}

In this study, NPP was predicted using CASA model for pure black pine stands in the Black Sea backward region of Turkey. The CASA model can be used efficiently that the region where this study was conducted. The satellite and climate data were required to run the CASA model and it was effort and time consumed. In addition, there was also the possibility of modeling with the stand increment $(r=0.87)$, growing stock $(r=0.88)$ and stand carbon $(\mathrm{r}=0.92)$ parameters that were correlated positively with the NPP in the study. Results of the variance analysis showed that optimal stand criteria for maximum NPP were detected in 0-40 years of age and 12-17 m mean dominant height, $11-70 \%$ of level of crown closure and 1300-1600 m of elevation. It was believed that these results can be helpful to create forest management plans considering maximum NPP operating objective studies in forest ecosystems or afforestation studies. Recently, black pine trees were used in afforestation in all around the Turkey to be coniferous, and this study can be a good guide to use the black pine for carbon absorption more efficiently. It is also very important to create a sustainable carbon budget strategy in country scale. 
Acknowledgements. We would like to thank to Turkish State Meteorological Service and General Directorate of Forestry for providing data.

\section{REFERENCES}

[1] Anonymous (2008): Forest Management Guidelines. - Republic of Turkey, General Directorate of Forestry, Forest Management and Planning Department, Ankara.

[2] Ardö, J. (2015): Comparison between remote sensing and a dynamic vegetation model for estimating terrestrial primary production of Africa. - Carbon Balance and Management 10(1): 8.

[3] Berberoglu, S., Evrendilek, F., Ozkan, C., Donmez, C. (2007): Modeling forest productivity using Envisat MERIS data. - Sensors 7(10): 2115-2127.

[4] Chen, S., Jiang, H., Jin, J., Wang, Y. (2016): Changes in net primary production in the Tianmu Mountain Nature Reserve, China, from 1984 to 2014. - Int. J. Remote Sens. 38: 211-234.

[5] Chen, W., Chen, J. M., Price, D. T., Cihlar, J. (2002): Effects of stand age on net primary productivity of boreal black spruce forests in Ontario, Canada. - Canadian Journal of Forest Research 32(5): 833-842.

[6] Cramer, W., Kicklighter, D. W., Bondeau, A., Iii, B. M., Churkina, G., Nemry, B., Ruimy, A., Schloss, A. L., Intercomparison, TPOTP. (1999): Comparing global models of terrestrial net primary productivity (NPP): overview and key results. - Glob. Chang. Biol. 5: 1-15.

[7] Değirmenci, A. S., Zengin, H. (2016): Ormanlardaki karbon birikiminin konumsal ve zamansal değişiminin incelenmesi: Daday planlama birimi örneği. - Artvin Çoruh Üniversitesi Orman Fakültesi Dergisi, Artvin Çoruh Üniversitesi Orman Fakültesi Dergisi 17(2): 177-187.

[8] Dong, Y., Whalley, J. (2010): Carbon, trade policy and carbon free trade areas. - The World Economy 33(9): 1073-1094.

[9] Donmez, C., Berberoglu, S., Cilek, A. (2015): Spatial variations of NPP in different altitudes at a mediterranean watershed. - Fresenius Environ. Bull. 24: 2264-2274.

[10] Donmez, C., Berberoglu, S., Cilek, A., Evrendilek, F. (2016): Spatiotemporal modeling of net primary productivity of Eastern Mediterranean biomes under different regional climate change scenarios. - International Journal of Environmental Research 10(2): 341356.

[11] Esser, G., Hoffstadt, J., Mack, F., Wittenberg, U. (1994): High Resolution Biosphere Model: Documentation Model, Version 3.00.00. - Institut für Pflanzenökologie, Justus-Liebig-Universität, Gießen.

[12] Evrendilek, F., Berberoglu, S., Taskinsu-Meydan, S., Yilmaz, E. (2006): Quantifying carbon budgets of conifer Mediterranean forest ecosystems, Turkey. - Environmental Monitoring and Assessment 119(1-3): 527-543.

[13] Field, C. B., Randerson, J. T., Malmström, C. M. (1995): Global net primary production: Combining ecology and remote sensing. - Remote Sens. Environ. 51: 74-88.

[14] Friend, A. D., Cox, P. M. (1995): Modelling the effects of atmospheric CO2 on vegetation-atmosphere interactions. - Agricultural and Forest Meteorology 73: 285295.

[15] Gower, S. T., Kucharik, C. J., Norman, J. M. (1999): Direct and indirect estimation of leaf area index, fAPAR, and net primary production of terrestrial ecosystems. - Remote Sensing of Environment 70(1): 29-51.

[16] Haxeltine, A., Prentice, I. C. (1996): BIOME3: an equilibrium biosphere model based on ecophysiological constraints, resource availability and competition among plant functional types. - Global Biogeochemical Cycles 10: 693709.

[17] Huang, N., Niu, Z., Wu, C., Tappert, M. C. (2010): Modeling net primary production of a fast-growing forest using a light use efficiency model. - Ecol. Modell. 221: 2938-2948. 
[18] Kaduk, J., Heimann, M. (1996): A prognostic phenology scheme for global terrestrial carbon cycle models. - Climate Research 6: 119.

[19] Klein, T., Siegwolf, R. T., Körner, C. (2016): Belowground carbon trade among tall trees in a temperate forest. - Science 352(6283): 342-344.

[20] Knorr, W., Heimann, M. (1995): Impact of drought stress and other factors on seasonal land biosphere $\mathrm{CO} 2$ exchange studied through an atmospheric tracer transport model. Tellus 47B: 471489.

[21] Li, Z., Zhou, T. (2015): Optimization of Forest Age-Dependent Light-Use Efficiency and Its Implications on Climate-Vegetation Interactions in China. - International Archives of the Photogrammetry, Remote Sensing and Spatial Information Sciences - ISPRS Archives, pp. 449-454.

[22] Liang, W., Yang, Y., Fan, D., Guan, H., Zhang, T., Long, D., Zhou, Y., Bai, D. (2015): Analysis of spatial and temporal patterns of net primary production and their climate controls in China from 1982 to 2010. - Agricultural and Forest Meteorology 204: 22-36.

[23] Liu, Z., Hu, M., Hu, Y., Wang, G. (2018): Estimation of net primary productivity of forests by modified CASA models and remotely sensed data. - International Journal of Remote Sensing 39(4) 1092-1116.

[24] Los, S. O., Pollack, N. H., Parris, M. T., Collatz, G. J., Tucker, C. J., Sellers, P. J., Malmström, C. M., DeFries, R. S., Bounoua, L., Dazlich, D. A. (2000): A Global 9-yr Biophysical Land Surface Dataset from NOAA AVHRR Data. - J. Hydrometeorol. 1: 183-199.

[25] Ma, Z., Liu, Q., Wang, H., Li, X., Zeng, H., Xu, W. (2008): Observation and modeling of NPP for Pinus elliottii plantation in subtropical China. - Science in China Series D: Earth Sciences 51(7): 955-965.

[26] McGuire, A. D., Melillo, J. M., Kicklighter, D. W., Joyce, L. A. (1995): Equilibrium responses of soil carbon to climate change - empirical and process-based estimates. Journal of Biogeography 22(4-5): 785796.

[27] Parton, W. J., Scurlock, J. M. O., Ojima, D. S., Gilmanov, T. G., Scholes, R. J., Schimel, D. S., Kirchner, T., Menaut, J. C., Seastedt, T., Garcia, Moya, E., Kamnalrut, A., Kinyamario, J. I. (1993): Observations and modeling of biomass and soil organic matter dynamics for the grassland biome worldwide. - Global Biogeochemical Cycles 7: 785 809.

[28] Pei, Y., Huang, J., Wang, L., Chi, H., Zhao, Y. (2018): An improved phenology-based CASA model for estimating net primary production of forest in central China based on Landsat images. - International Journal of Remote Sensing 1-29.

[29] Potter, C. S., Randerson, J. T., Field, C. B., Matson, P. A., Vitousek, P. M., Mooney, H. A., Klooster, S. A. (1993): Terrestrial ecosystem production: A process model based on global satellite and surface data. - Global Biogeochem. Cycles 7: 811-841.

[30] Potter, C. S., Davidson, E. A., Klooster, S. A., Nepstad, D. C., De Negreiros, G. H., Brooks, V. (1998): Regional application of an ecosystem production model for studies of biogeochemistry in Brazilian Amazonia. - Global Change Biology 4(3): 315-333.

[31] Potter, C. S., Klooster, S., Myneni, R., Genovese, V., Tan, P. N., Kumar, V. (2003): Continental-scale comparison son terrestrial carbon sinks estimated from satellite data and ecosystem modeling 1982-1998. - Global and Planetery Change 39: 201-213.

[32] Potter, C. S., Klooster, S., Steinbach, M., Tan, P., Sheikarand, S., Carvalho, C. (2004): Understanding global teleconnections of climate to regional model estimates of amazone ecosystem carbon fluxes. - Global Change Biology 10: 693-703.

[33] Potter, C., Klooster, S., Genovese, V. (2012): Net primary production of terrestrial ecosystems from 2000 to 2009. - Climate Change 115(2): 365-378.

[34] Prince, S. D. (1991): A model of regional primary production for use with coarse-resolution satellite data. - International Journal of Remote Sensing 12: 13131330. 
[35] Ruimy, A., Dedieu, G., Saugier, B. (1996): TURC: a diagnostic model of continental gross primary productivity and net primary productivity. - Global Biogeochemical Cycles 10: 269286.

[36] Ruimy, A., Kergoat, L., Bondeau, A. et al. (1999): Comparing global models of terrestrial net primary productivity (NPP): Analysis of differences in light absorption and light-use efficiency. - Global Change Biology 5(S1): 56-64.

[37] Şatır, O., Berberoğlu, S. (2012): Land Use/Cover Classification Techniques Using Optical Remotely Sensed Data in Landscape Planning. - Ozyavuz, M. (ed.) Landscape Planning. Intech Open, London.

[38] Schloss, A. L., Kicklighter, D. W., Kaduk, J., Wittenberg, U., Model, POTPN. (1999): Comparing global models of terrestrial net primary productivity (NPP): comparison of NPP to climate and the Normalized Difference Vegetation Index (NDVI). - Global Change Biology 5(S1): 25-34.

[39] Sellers, P. J., Los, S. O., Tucker, C. J., Justice, C. O., Dazlich, D. A., Collatz, G. J., Randall, D. A. (1996): A revised land surface parameterization (SiB2) for atmospheric GCMs. Part II: The generation of global fields of terrestrial biophysical parameters from satellite data. - Journal of Climate 9: 706737.

[40] Taskınsu Meydan, H. S., Berberoğlu, S. (2008): Yukarı Seyhan Havzası'nda Uzaktan Algılama Yöntemleri İle Arazi Örtüsünün Sinıflandırılması Ve Bazı Orman Meşcerelerinde Verimliliğin Modellenmesi. - ÇÜ Fen Bilimleri Enstitüsü, 18-1.

[41] Tolunay, D. (2011): Total carbon stocks and carbon accumulation in living tree biomass in forest ecosystems of Turkey. - Turkish J. Agric. For. 35: 265-279.

[42] Tripathi, P., Patel, N. R., Kushwaha, S. P. S. (2018): Estimating net primary productivity in tropical forest plantations in India using satellite-driven ecosystem model. - Geocarto International 33(9): 988-999.

[43] Turner, D. P., Ritts, W. D., Cohen, W. B., Gower, S. T., Running, S. W., Zhao, M., Costa, M. H., Kirschbaum, A. A., Ham, J. M., Saleska, S. R., Ahl, D. E. (2006): Evaluation of MODIS NPP and GPP products across multiple biomes. - Remote Sensing of Environment 102(3-4): 282-292.

[44] Wang, B., Li, M., Fan, W., Yu, Y., Chen, J. M. (2018): Relationship between net primary productivity and forest stand age under different site conditions and its implications for regional carbon cycle study. - Forests 9: 5.

[45] Wang, L., Gong, W., Ma, Y., Zhang, M. (2013): Modeling Regional Vegetation NPP Variations and Their Relationships with Climatic Parameters in Wuhan, China. - Earth Interactions 17: 1-20.

[46] Woodward, F. I., Smith, T. M., Emanuel, W. R. (1995): A global land primary productivity and phytogeography model. - Global Biogeochemical Cycles 9: 471490.

[47] Zhu, W., Pan, Y., He, H., Yu, D., Hu, H. (2006): Simulation of maximum light use efficiency for some typical vegetation types in China. - Chinese Sci. Bull. 51: 457-463.

[48] Zhang, Y., Zhang, X. (2017): Estimation of net primary productivity of different forest types based on improved CASA model in Jing-Jin-Ji region, China. - Journal of Sustainable Forestry 36(6): 568-582. 